\title{
COURTS, LEGAL CULTURE AND EU ENLARGEMENT
}

\author{
Tamara Ćapeta*
}

\begin{abstract}
Summary: The Article deals with the differences in the legal culture in the pre-2004 and post2004 EU Member States and candidate states and examines whether such differences prevent successful participation of new Member States' courts in the Community legal order. Comparing three elements of legal culture, namely valid legal sources, interpretation of the law and argumentation by the courts, the author concludes that important differences do exist. It is further examined whether the last or future enlargements could endanger the functioning of the Community legal order due to the still existing differences in legal culture. The conclusion is that the membership is possible despite the differences, as with proper basic education in Community law, the judges will not endanger its application. On the other hand, in order to participate fully in the Community legal order, i.e. in order to acquire the ability to participate in the constitutional discourse in the EU, East European judges will need more time. However, EU membership may indeed only speed up the necessary process of changes in the legal culture.
\end{abstract}

\section{Introduction}

This article concerns changes in the judicial branch in Croatia which are necessary in order to fulfil the requirements of EU membership. The judiciary is at the top of the list of EU preaccession instruments for Croatia, such as the European Commission's opinion on its application for membership ${ }^{1}$ or the Decision establishing a pre-accession framework for Croatia (European Partnership). ${ }^{2}$ However, these documents do not specify what kind of reform of the judiciary is necessary. In public discourse, the backlog of cases and the length of the judicial process are usually mentioned. Without denying the importance of these problems in the Croatian judicial system, this article deals with a different type of adjustment that will be necessary, namely, a change in judges' understanding of the law and their own role in society.

The European Commission's opinion on Croatia's application for EU membership states: “In this regard, alignment with the acquis is a necessary but not sufficient condition to meet the obligations of EU membership. Croatia must also take all necessary measures to create the necessary implementing structures, to bring administrative and judicial capacities to the required level and to ensure effective enforcement". ${ }^{3}$ Although the Commission continues by stating that "analysis and assessment of Croatia's administrative and judicial capacities is therefore incorporated into each of the chapters analysed below", ${ }^{4}$ one does not find any

\footnotetext{
- Docent, Department of European Public Law, Faculty of Law, University of Zagreb. This article has been completed in February 2005.

${ }^{1}$ European Commission Opinion on Croatia's application for membership of the European Union [2004] COM 257 final,, 20 April 2004.

${ }^{2}$ Council Dec. 2004/648 [2004] OJ L 297/19 of 13 September 2004 on the principles, priorities and conditions contained in the European Partnership with Croatia.

${ }^{3}$ European Commission Opinion on Croatia's Application for Membership of the European Union, see n. 1, p. 54.

${ }^{4}$ Ibid.
} 
assessment of judicial capacity in the pages that follow. What is, therefore, the "required level of judicial capacity" that needs to be reached for successful EU membership?

In order to answer this question, this article starts by explaining what the European role of national judges is, based on the author's understanding of developments in the EU legal order. I then continue by arguing that there are still significant differences in legal culture in older EU Member States and new, ex-communist Member States or candidate countries, and that this difference prevents the newcomers' national courts from assuming the constitutionalising role which national courts have in the EU legal order. This cultural difference has been demonstrated mainly by using the example of Croatia; however, references to other excommunist legal orders are also included.

In the last part of the article, I pose the question of whether the lack of ability to participate in shaping the "new legal order" means that new Member States' ${ }^{5}$ courts will endanger the existing EU legal system, and whether this can be used as an argument to postpone membership of other countries which are currently bidding for it, ${ }^{6}$ including Croatia. For this purpose, the constitutionalising task that judges have has been separated from tasks they have as general judges of Community law. I conclude that, with proper education, judges can learn to function as Community judges. Participation in the application of Community law should speed up a change in legal culture, which will, in time, allow judges to become active participants in the shaping of the Community legal order as well.

\section{National Courts in the EU Legal Order}

The two European courts - the European Court of Justice (ECJ) and the Court of First Instance (CFI) - are courts of limited jurisdiction, as they may only decide those types of cases for which the Treaties ${ }^{7}$ has accorded them jurisdiction. ${ }^{8}$ All other cases which involve the application of Community law, but are not in their jurisdiction, are to be resolved by national courts. Such wide role of national courts is not clearly mentioned anywhere in the Treaties. ${ }^{9}$ This is regrettable when considered in terms of enlargement, as more clear

\footnotetext{
5 The term "new Member States" in this article denotes the eight ex-communist countries that became EU members in May 2004, namely, the Czech Republic, Estonia, Hungary, Latvia, Lithuania, Poland, Slovakia and Slovenia. Besides these, two other countries, Cyprus and Malta, joined in 2004; but they did not have communist pasts, and so their legal systems developed differently.

${ }^{6}$ The waiting list for EU membership today contains five countries, of which four are ex-communist (Bulgaria, Croatia, Macedonia and Romania) and one is not (Turkey). Negotiations for membership with Bulgaria and Romania were opened in December 1999, and are almost completed. Croatia was accepted as a candidate country by the European Council's decision at its meeting on 18 and 19 June 2004, with the beginning of accession negotiations scheduled for 17 March 2005 at the Brussels European Council in December 2004. Macedonia applied for membership on 22 March 2004, and is awaiting the Commission's opinion regarding its application. There are several other ex-communist countries which might apply in the future, such as BosniaHerzegovina, Serbia and Montenegro, or Albania. This makes the last wave of enlargement an important example for future enlargements.

${ }^{7}$ Under the term Treaties, I understand the Treaty establishing the European Community, the Treaty establishing the European Atomic Energy Community and the Treaty on European Union. The latter, however, accords rather limitted jurisdiction to the ECJ.

${ }^{8}$ Regarding the organisation and jurisdiction of these two courts, see, for example, N. Brown and T.Kennedy, The Court of Justice of the European Communities, Sweet and Maxwell, $5^{\text {th }}$ edition, 2000.

${ }^{9}$ The only place in which national courts are mentioned is Article 234 TEC. Their role in the EC legal system has been clarified mostly via case law. Proposals for clarifying their powers and obligations in the text of the Treaty were not accepted at the last Treaty revision in Nice. (See the Additional Commission's contribution to the Intergovernmental Conference on Institutional Reform: Reform of Community courts, [2000] COM 109
} 
indication in the basic text that national courts have to apply Community law would encourage judges from new Member States to do so. ${ }^{10}$ Notwithstanding such 'gap' in the Treaties, nobody today disputes that, in the Community legal order, national courts act as "courts of general jurisdiction" for questions of Community law. ${ }^{11}$

This is especially important when it comes to the rights of individuals under Community norms. ${ }^{12}$ When protecting individual rights of Community origin, ${ }^{13}$ national courts are bound by certain Community law principles, which assign to them certain powers and obligations that do not necessarily exist in, or are even contrary to, the internal legal systems within which they operate. ${ }^{14}$ Thus, for example, they are obliged to disapply internal statutes that contradict Community law, even if they are not allowed to do so under internal rules. ${ }^{15}$ Likewise, in the name of the principle of effective judicial protection, the ECJ has required national courts to change their internal procedural and remedial rules. Thus national courts may be asked to question their internal statutes of limitation ${ }^{16}$ and, if necessary, to change them. The same may happen to rules on evidence, ${ }^{17}$ standing, ${ }^{18}$ and so forth. National courts may be asked to provide remedies that do not exist under national law, such as interim injunctions against the Crown, ${ }^{19}$ damages against the legislative state,${ }^{20}$ or calculating interest on the amount of damages they award, even though this is not permitted under national law. ${ }^{21}$

final, 1.3.2000.) Nor will this situation change with the new Constitutional Treaty, which is awaiting ratification. See P. Steinberg, A Tentative Survey of the Innovations of the Constitution for Europe that Might Impact upon National Constitutional Law, Walter Hallstein-Institut für Europäisches Verfassungsrecht, WHI - Paper 14/03, p. 148-150.

${ }^{10}$ Tamara Ćapeta, Preliminary Ruling Procedure after Nice, in: The European Union Economic System and the Republic of Croatia's Accession, Faculty of Economics, University of Rijeka, Rijeka, 2001, p. 500.

${ }^{11}$ J. Temple Lang, The Duties of National Courts under Community Constitutional Law, [1997] 22 ELRev. 3. See also D. Simon, Les exigences de la primauté du droit communautaire: continuité ou métamorphoses?, in: L’Europe et le droit, Mélange en hommage à Jean Boulouis, Dalloz, Paris, 1991, p. 482.

${ }^{12}$ Individuals have standing in European courts (the CFI in the first instance) only in actions brought against Community institutions (in proceedings for annulment of the act of an institution, for failure to adopt an act, and for damages). Even where the Treaty does enable individuals to come directly before European courts, conditions for their standing in these courts are narrowly interpreted by the ECJ. For an overview and critique, see E. Biernat, The Locus Standi of Private Applicants under Article 230 (4) EC and the Principle of Judicial Protection in the European Community, Jean Monnet Working Paper 12/03; P. Craig, Standing, Right and the Structure of Legal Argument, [2003] 9 EPL 493; J.Usher, Direct and individual concern - an effective remedy or a conventional solution?, [2003] 28 ELRev. 575. Thus, most disputes about rights which individuals have on the basis of Community norms must be resolved by existing courts in the Member States.

${ }^{13}$ The term "right of Community origin" embraces not only rights which individuals derive directly from Community norms, but also rights derived from the internal legal norms enacted in implementation of Community law. The latter category of rights are also Community rights with regard to their origin, and national norms must, therefore, be interpreted in accordance with the Community norms they implement.

${ }^{14}$ For more, see T. Ćapeta, Sudovi Europske unije. Nacionalni sudovi Kao Europski sudovi. IMO, Zagreb, $2002 ;$ M. Claes, The National Courts' Mandate in the European Constitution, forthcoming from Hart Publishing, 2005.

${ }^{15}$ See Case 106/77 Amministrazione delle Finanze dello Stato v. Simmenthal S.p.A., [1978] ECR 643.

${ }^{16}$ E.g. Case 33/76 Rewe-Zentralfinanz $e G$ and Rewe-Zentral $A G$ v. Landwirtschaftskammer für das Saarland, [1976] ECR 1989; case C-231/96 Industriale Siderurgica Srl (Edis) v. Ministero delle Finanze, [1998] ECR I-4951.

${ }^{17}$ E.g. Case 199/82 Amministrazione delle Finanze dello Stato v. SpA San Giorgo, [1983] ECR 3595.

${ }^{18}$ E.g. joined Cases C-87-89/90 A. Verholen and others v. Sociale Verzekeringsbank Amsterdam, [1991] ECR I-3757.

${ }^{19}$ Case C-213/89 The Queen v. Secretary of State ex parte Factortame Ltd. and Others, (1990) ECR I-2433.

${ }^{20}$ Joined Cases C-46 and 48/93 Brasserie du Pêcheur v. Germany and The Queen v. Secretary of State for Transport, ex parte: Factortame Ltd and others (Factortame III), [1996] ECR I-1066.

${ }^{21}$ Case C-271/91 M.H. Marshall v. Southampton and South West Hampshire Area Health Authorities (Marshall II), [1993] ECR I-4367. 
Most of this judicial acquis communautaire ${ }^{22}$ is judge-made law. In order to be able to apply Community law properly, national judges need to be familiar with it. This may cause certain problems for judges who, as is the case in Croatia, are not used to keeping up with the case law of courts even in their own country. Second, and more importantly, the application of principles defining the powers of judges in Community law also demands a certain measure of creativity from judges. As will be shown below, judges from ex-communist countries often lack this ability.

If applying Community law and enforcing Community rights may sometimes be a complex task for national judges, it is not an impossible one. With appropriate education, any judge can learn enough to be able to apply Community law properly. However, besides the aforementioned task of applying and enforcing Community law, there is another, less visible but more demanding role for national judges. This concerns their place in the process of shaping the Community legal order. If, as Weiler describes it, "constitutionalism is the DOS or Windows of the European Community", ${ }^{23}$ then the national courts of EU Member States are at least an exe programme, without which the operating system cannot run. Not only could the "new legal order" not be enforced without national courts; without their participation it would never have been created. ${ }^{24}$

Quite often, national courts that have brought important constitutional questions to judicial and subsequently wider discourse, usually by way of a preliminary ruling, were courts of lower instance, and not the highest courts in the country. ${ }^{25}$ It will suffice to mention only a few examples here. In Van Gend en Loos, the preliminary question under the former Article $177 \mathrm{EC}^{26}$ was referred by the Tariefcommisie, the court of first instance for financial matters in the Netherlands. ${ }^{27}$ The supremacy doctrine was elaborated for the first time in Costa $v$. $E N E L$, on a reference by the Giudice Conciliatore of Milan, ${ }^{28}$ and later, in Simmenthal II, on a reference by an Italian Pretore from Susa. ${ }^{29}$ The Italian Pretori have had a significant role in the development of some other principles of constitutional significance. Thus, for example, when the Pretori of Vicenza and Bassano di Grapa asked whether they could hold their state responsible for damages for not properly implementing a Community directive in the cases Francovich and Bonifaci, the development of the Community principle of state liability for damages was begun. ${ }^{30}$ Yet not only Italian judges have initiated the development of new principles of a constitutional character. For example, in the Defrenne II case ${ }^{31}$ the Cour de travail of Brussels enabled the development of the doctrine of horizontal direct effect and the transformation of the equal pay principle into the general principle of gender equality in EC

\footnotetext{
${ }^{22}$ T. Ćapeta,, Judicial acquis communautaire, in: EU Adjustment to Eastern Enlargement. Polish and European Perspectives, Anna Zielinska-Glebocka and Andrej Stepniak (eds.), Fundacja Razwoju, Uniwersytetu Gdanskiego, Gdansk, 1998, p. 80.

${ }^{23}$ J.H.H. Weiler, The Reformation of European Constitutionalism, [1997] 35/1/ JCMS 97.

${ }^{24}$ The importance of national courts as actors in the EU political process has been recognised by other disciplines, such as the political sciences. See K. Alter, Establishing the Supremacy of European Law, Oxford University Press, 2001. See also the study published by Slaughter, Stone Sweet and Weiler, THE EuropeAN Courts and National Courts. Doctrine and Jurisprudence, Hart Publishing, Oxford, 1998.

${ }^{25}$ On the relationship between the ECJ and the highest national courts, see F.C. Mayer, The European Constitution and the Courts. Adjudicating European constitutional law in a multilevel system, Jean Monnet Working Paper 9/03.

${ }^{26}$ Now Article 234 EC.

${ }^{27}$ Case 26/62 Van Gend en Loos v. Nederlandse Administratie der Belastingen, [1963] ECR 1.

${ }^{28}$ Case 6/64 Flaminio Costa v. ENEL [1964] ECR 585.

${ }^{29}$ Simmenthal II, see n. 15

${ }^{30}$ Joined cases C-6/90 and C-9/90 Andrea Francovich and Danila Bonifaci and Others v. Italian Republic, [1991] ECR I5357.

${ }^{31}$ Case 43/75 Gabrielle Defrenne v. Sabena, [1976] ECR 455.
} 
law. English courts have pushed forward the development of the direct effects doctrine with regard to directives: the High Court (Chancery Division) in Van Duyn ${ }^{32}$ enabled the ECJ to establish the principle whereby directives may have direct effects, while a reference by the Court of Appeal of England and Wales in Marshall gave the ECJ an opportunity to restrict such effects to vertical relations only. ${ }^{33}$ On a reference by the German Arbeitsgericht of Hamm in Von Colson and Kamman, ${ }^{34}$ the ECJ spelled out the principle of indirect effects, while it was due to a reference by the Spanish Juzgado de Primera Instancia e Instrucción no. 1 de Oviedo in Marleasing ${ }^{35}$ that this principle was further elaborated.

All these courts, and many others, had challenged a domestic rule of constitutional character or a longstanding interpretation of the legal order in their country. For instance, the rule of recognition, in Hart's usage, ${ }^{36}$ was questioned when a decision on whether Community law is law in the domestic legal order, and what effects it has in that order, was taken out of the ambit of the domestic constitution. The long-cherished supremacy of the Parliament doctrine was questioned when the English judiciary accepted the possibility of granting injunctions against the Crown after the Factortame case, ${ }^{37}$ or when parliaments were held responsible for damages by not legislating in Brasserie de Pecheurs and Factortame III. ${ }^{38}$

Part of the EU Constitution was thus developed through judicial challenges to the internal legal order.

Another way in which national courts have pushed for further elaboration of the European Constitution was by challenging the EU constitutional scheme, either via the preliminary ruling procedure or outside it. The best-known example of this was the German Federal Constitutional Court's refusal to accept the supremacy of Community law without adequate protection of human rights at the EU level. ${ }^{39}$ This led to the development of the constitutional doctrine in EU law, whereby human rights were introduced in the EC legal order by way of the general principles of Community law. ${ }^{40}$ Sometimes attempts by national judges to change established principles of Community law by referring to the ECJ have not been successful, yet have still made a difference by putting the issue on the agenda. Thus, for example, the Italian Giudize Conciliatore of Florence has challenged the doctrine according to which directives cannot have a horizontal direct effect, ${ }^{41}$ albeit without success for the time being. His attempt has, however, opened a lively discussion about the issue. ${ }^{42}$

\footnotetext{
${ }^{32}$ Case 41/74 Yvonne Van Duyn v. Home Office, [1974] ECR 1337.

${ }^{33}$ Case 152/84 M.H. Marshall v. Southampton and South-West Hampshire Area Health Authority, [1986] ECR 723.

${ }^{34}$ Case 14/83 Sabine von Colson and Elisabeth Kamann v Land Nordrhein-Westfalen, [1984] ECR 1891.

${ }^{35}$ Case C-106/89 Marleasing SA v. La Comercial Internacional de Alimentacion SA, [1990] ECR I-4135.

${ }^{36}$ H.L.A. Hart, The Concept of Law, $2^{\text {nd }}$ edition, Clarendon Press, Oxford, 1994.

${ }^{37}$ Factortame, see n.19

${ }^{38}$ Brasserie de Pecheurs and Factortame III, see n.20

${ }^{39}$ Internationale Handelsgeselschaft $\mathrm{mbH}$ v. Einfuhr-und Vorratsstelle für Getreide und Futtermittel. (Solange I), published in French in (1975) CDE; Wünche Handelsgesellschaft (Solange II), published in English in (1987) 3 CMLR 225

${ }^{40}$ Starting with Case 11/70 Internationale Handelsgeselschaft mbH v. Einfuhr-und Vorratsstelle für Getreide und Futtermittel, [1970] ECR 1125. The outcome of this interplay between national and Community courts is the EU Charter of Fundamental Rights, which will become binding when and if the Treaty establishing a Constitution for Europe is ratified by all Member States. For more about the dialogue between the German Federal Constitutional Court and the ECJ, see J. Kokott, Report on Germany, in: The European Courts And National Courts. Doctrine and Jurisprudence, Hart Publishing, Oxford, 1998, p.77.

${ }^{41}$ In case C-91/92 Paola Faccini Dori v. Recreb Srl, [1994] ECR I-3325.

${ }^{42}$ Several Advocate Generals in the ECJ were defending his position. See Opinion of AG Lenz in the case Faccini Dori (see n. 41); Opinion of AG Jacobs in the case C-316/93 Vaneetveld [1994] ECR I-736; Opinion of
} 
Although many issues of constitutional significance for the European legal order have already been settled, ${ }^{43}$ the process of constitutionalisation and, therefore, of constitutional dialogue between the national and European judiciaries as well is far from over. ${ }^{44}$

In conclusion to this first part of the article, it is important to stress that the judges who initiated the creation or refinement of European constitutional principles were willing to challenge established legal rules by opposing them to certain other values which they believed had been neglected by such rules. They challenged either domestic rules, relying on the new values imported by the new European legal order, or the newly-established rules of the European legal order, defending the values of the domestic legal order. They were creative judges who used all the possibilities of the two legal orders to try and improve legal rules. ${ }^{45}$

\section{Differences in Legal Culture and the Constitutionalising Role of Judges}

As European judges, national judges need to be able to participate in European constitutional discourse. ${ }^{46}$ Are Central and Eastern European judges ready for this constitutionalising role, are they ready to participate in shaping the Constitution for Europe? In this section, drawing mostly on the example of Croatia, I will try to show that a long tradition of strict formalism and positivism in Central and Eastern Europe leaves judges there unprepared for their constitutionalising role. A longer time will be necessary to adjust to this requirement of the European legal order.

Without any ambition of providing a detailed analysis (which has been done by others ${ }^{47}$ ), I wish to point out the existing differences between the predominant legal cultures in the EU

AG Van Gerven in the case Marshall II (see n.21). The scholars have also participated in the discussions. See, for example, W. Van Gerven, The Horizontal Effect of Directive Provisions Revisited: The Reality of Catchwords, in: Institutional Dynamics of European Integration, Essays in Honour of Henry G. Schermers, ed. by Deirdre Curtin \& Ton Heukles, Vol II, Martinus Nijhoff Publishers, Dordrechts/Boston/London, 1994, p. 334; J.Coppel, Rights, Duties and the End of Marshall, (1994) 57 MLR 859; F. Emmert and M. Pereira de Azevedo, Les jeux sont fait: rien ne va plus ou une nouvelle occasion perdue par la CJCE, (1995) RTDE 11.

${ }^{43} \mathrm{Or}$, it is possible that such questions will never be finally settled. Thus, for example, the last enlargement (2004) reopened the question of final authority in a fundamental rights violation by Community law. See, in this regard, A.Sajó, Learning Co-operative Constitutionalism the Hard Way: The Hungarian Constitutional Court Shying Away from EU Supremacy, (2004) 3 ZSE 351.

44 One of the unsettled questions was put on the agenda by the Maastricht decision of the German Bundesverfassungsgericht (published in English in (1994) 1 CMLR 57). This concerns the division of competences in a federal-like legal order such as that of the EU. The issue is who (which court) is competent to judge whether the EU has acted outside the competences transferred to it by the Founding Treaty. Enactment of the new Treaty, which bears the name of a Constitution, will not solve this and similar issues in and of itself. Therefore, the dialogue between European and national judiciaries on issues important for the EU legal order will continue.

${ }^{45}$ I cannot, however, claim that the entire judiciary in every older EU Member State is able to, or does, participate in constitutional discourse. Neither the Commission's Annual Reports on the application of Community law (published annually at europa.eu.int/comm/secretariat_general/sgb/droit_com/index_en.htm) nor the statistics published on the web page of the European Court (curia.eu.int/) give enough information to enable valid conclusions. What is important, however, is that even if only some of the courts in older Member States participate in the constitutionalisation process, this does not prevent us from concluding that the legal culture in those countries differs from that prevailing in the new Member States or candidate countries, which emerged from the collapse of communism.

${ }^{46}$ This is not to say that the same qualities are not welcome within the internal legal order. On the contrary, I will argue that precisely because Croatian judges lack these qualities in internal law, they are not yet prepared for their European role. 
and its older Member States ${ }^{48}$ on the one hand, and those in Central and Eastern European countries, on the other. By the term "legal culture" I understand the prevailing opinion in a society on the purpose of the law and the role of different institutions within the legal order, as well as the way in which legal rules are interpreted. John Bell has defined legal culture as "a specific way in which values, practices and concepts are integrated into the operation of legal institutions and the interpretation of legal texts". ${ }^{49}$

In the European countries of the $20^{\text {th }}$ century political "West", the realism movement influenced the prevailing understanding of law, albeit to a much lesser degree than in the USA. Strong formalism was replaced by a more pragmatic approach to the law. This also influenced the understanding of the roles of different actors, including courts. It was more or less openly ${ }^{50}$ admitted that courts participate in the process of creating law, and thus they have also been perceived as political actors. ${ }^{51}$ The change in the perception of the place of the judiciary in the society was also significantly influenced by the participation in the European integration process. Pragmatic case law of the European Court of Justice influenced the national judiciaries of the EC/EU Member States.

On the other hand, the political "East" of the European continent was not exposed to this change in legal thinking. ${ }^{52}$ The positivism that followed the major codifications of the $19^{\text {th }}$ century remained the prevailing understanding of law throughout the $20^{\text {th }}$ century and into the $21^{\text {st }}$. Formalism became even stronger in these countries. Courts were mere exponents of the law, and the law was what was written in the legal codes. ${ }^{53}$ After the fall of the communist regimes at the end of the 1980s many legal norms changed, but the general understanding of what the law was could not change overnight. These legal systems are now being transformed and exposed to different theories of law; however, a change in legal culture takes time. The process of gradual integration into the EU should help to speed up the transformation of Central and Eastern European legal cultures.

\footnotetext{
${ }^{47}$ M.Cappelletti, The Judicial Process in Comparative Perspective, Clarendon Press, Oxford, 1989, especially Part I entitled: The evolving role and responsibility of judges. M.W. Hesselink, The New European Legal Culture, Nijhoff, 2001. Z. Kühn, Worlds Apart. Western and Central European Judicial Culture at the Onset of the European Enlargement, American Journal of Comparative Law 2005, forthcoming.

${ }^{48}$ The term "older member States" is used to denote EU Member States prior to the 2004 enlargement.

${ }^{49}$ J. Bell, English Law and French Law - Not So Different? (1995) CLP 69, p. 70; quoted as per Hoecke and Warrington, Legal Cultures, Legal Paradigms and Legal Doctrine: Towards a New Model for Comparative Law, (1998) 47 ICLQ 495, p. 498.

${ }^{50}$ In some countries this is not obvious at first. The French judiciary, for example, maintains the outward impression of being completely outside any political process, of being a mechanic applier of the legal rules contained in the code. The situation is quite different if one looks behind its brief and formalistic published judgments. See, in this regard, M. Lasser, Anticipating Three Models of Judicial Control, Debate and Legitimacy: The European Court of Justice, the Cour de cassation, and the United States Supreme Court, Jean Monnet Working Paper 1/03, especially p. 5-23.

51 A. Stone Sweet, Constitutional Politics: The reciprocal impact of lawmaking and constitutional adjudication, in: Lawmaking in the European Union, Paul Craig and Carol Harlow (eds.), Kluwer Law International, 1998, p. 111. A. Stone Sweet, Governing with Judges. Constitutional Politics in Europe, OUP, 2000.

${ }^{52}$ Z. Kühn, Worlds Apart. Western and Central European Judicial Culture at the Onset of the European Enlargement, American Journal of Comparative Law 2005, forthcoming.

${ }^{53}$ One possible explanation for the strong judicial formalism in communist states is that judges stuck to the letter of the law in order to avoid influence by the Communist Party, which attempted to sway the courts towards interpretations of the law that suited its political goals.
} 
Legal culture in Croatia is also still largely positivistic and formalistic. ${ }^{54} \mathrm{~A}$ view of the law as a set of written rules is not only common among Croatian judges, but also among lawyers in general and the public at large. The best example of this is the typical usage of the word 'law' in the media (both TV and newspapers), as well as the writings of lawyers, where it is given as zakon, meaning "statute", and not as pravo, meaning "law". Courts are still understood as impersonal, rational institutions, able to objectively apply legal rules, yet having no role in the law-making process. Courts, therefore, cannot have a judicial policy, as their only task is to resolve individual cases by applying objective rules of law that contain all the answers. ${ }^{55}$

In order to compare legal cultures, I will use the model proposed by Hoecke and Warrington. ${ }^{56}$ They identify the following elements as factors in building a paradigm for legal culture: (i) a concept of law - what law is and its relation to other social norms; (ii) a theory of valid legal sources; (iii) a methodology of law, both for making and for adjudicating it, primarily a theory of interpretation; (iv) a theory of argumentation - what kind of arguments are accepted, i.e. only legal ones or others as well?; (v) a theory of legitimisation; and (vi) a common basic ideology - common basic values and a common basic world view. These elements may be used for comparisons on the macro level between different legal families, for example, between European law and Asian law, but also for comparisons on the micro level, including detecting differences in the understanding of the law by different actors within the same legal system (for example, civil and administrative jurisdictions) ${ }^{57}$

Although it can probably be demonstrated that all these elements differ in some respect between Western and Eastern Europe, I will try to illustrate differences in terms of three of the enumerated elements, namely, those contained in (ii), (iii) and (iv). These differences are large enough to justify a conclusion that the legal cultures in these societies differ. And it is precisely this difference that renders Eastern European judges unable to participate in European constitutional discourse.

\section{a) Valid Legal Sources}

On a theoretical level, the systematisation of valid legal sources in the legal systems of Western and Eastern Europe does not differ considerably. Thus, in all these countries constitutional norms are at the top of the hierarchy, followed by statutes and by-laws. General principles of law are often included among the legal sources. International law, written or unwritten, is another source of law, although this is not entirely visible in dualistic legal systems. Likewise, in legal textbooks it is accepted that case law also represents a kind of legal source. ${ }^{58}$ Among the sources that are not formally legally binding, yet can inform judges in the adjudication process, textbooks mention various types of soft law and, quite often, legal

\footnotetext{
${ }^{54}$ See also S. Rodin, Discourse and Authority in European and Post-Communist Legal Culture, published in this issue.

${ }^{55}$ See, for example, Ž. Horvatić, Problem odnosa u zakonu propisane i sudskim presudama primijenjene kaznenopravne represije prema počiniteljima kaznenih djela, (2004) 11 Hrvatski ljetopis za kazneno pravo i praksu/Croatian Annual of Criminal Law and Practice 381, on p. 388: "In modern states organised in accordance with the principle of the separation of powers, judicial power does not, and cannot, have any sort of 'policy', nor may its action when applying the law be described in that way". (In the original: "Sudbena vlast u suvremenim državama koje su organizirane po načelu diobe vlasti nema niti može imati bilo kakvu 'politiku', niti se tako može označavati njezino djelovanje kada primjenjuje zakon”).

${ }^{56}$ Hoecke and Warrington, Legal Cultures, Legal Paradigms and Legal Doctrine: Towards a New Model for Comparative Law, (1998) 47 ICLQ 495, p. 514-515.

${ }^{57}$ Ibid, p. 515.

${ }^{58}$ Usually referred to in Croatian legal textbooks as indirect source of law. See, for example, M.Vedriš and P. Klarić, GraĐANSKo PRAVO, Narodne novine, Zagreb, 2003, p. 22.
} 
doctrine. Differences regarding legal sources, though not visible in theory, do, however, exist in practice, i.e. in what legal sources are really used in the judicial process.

In the older EU Member States and the EU legal system itself, all the types of legal norms enumerated above are used as legal sources in judicial practice. Apart from written legal acts, unwritten legal rules, usually called general principles of law, play an important role in adjudication. A number of formally non-binding sources, or soft laws, ${ }^{59}$ are used as a persuasive authority when judges are deciding disputes. Policies, expressed in different forms, also inform judges in their adjudication. Case law occupies an important place among the sources of law, almost as much in the countries of continental Europe as in the common law countries. ${ }^{60}$ Legal doctrine is also important, although this is more evident in some countries, like Germany, than in others like France and the UK. Moreover, these legal sources have lost their strict Kelsenian hierarchical order; indeed sometimes, for instance, regarding the question of hierarchy between EU and domestic constitutions, an insistence on hierarchy would block the operation of the law.

In contrast, in Central and Eastern European countries, including Croatia, only the written legal sources that form part of domestic law are used by judges in practice. Judges rarely apply any other rules than statutory rules and by-laws in the adjudication process. Croatia's Act on Courts ${ }^{61}$ enumerates the legal acts which constitute sources of law for judges: the Constitution, statutes, ratified international treaties, and other acts adopted in accordance with the Constitution, international treaties, and the Statute. Although the Constitution is among the sources of law thus enumerated, ${ }^{62}$ courts rarely apply it. The same is true for international treaties. ${ }^{63}$ Thus the principal sources of law for judges are the Statute and the by-laws passed in order to implement it. Courts almost never refer to any other sources besides these.

A Kelsenian hierarchy exists among these acts, with the Constitution at the top of the pyramid. However, even though every statute must comply with the Constitution, judges never question their constitutionality. Under Croatia's constitutional order, judges do not possess the power to disapply statutes on their own. If they consider that a statute should not be applied, they have the procedural instrument of preliminary constitutional review at their disposal, namely, reference to the Constitutional Court. ${ }^{64}$ Judicial review of statutes is thus centralised, yet still enables ordinary judges to question their validity, although they may not determine this themselves. However, in the 14 years the new constitutional order has existed, there has not been a single preliminary reference for constitutional review to the

\footnotetext{
${ }^{59}$ For a study on the use of soft law instruments in the EU, see L. Senden, Soft Law in European Community Law. Its Relationship to Legislation, forthcoming from Hart Publishing, 2005.

${ }^{60}$ See, for example, T. Koopmans, Stare Decisis in European Law, Essays in European Law and Integration, ed. by David O'Keeffe and Henry G. Schrermers, Kluwer-Deventer/the Netherlands, 1982., p. 11; M. Cappelletti, The Doctrine of Stare Decisis and the Civil Law: A Fundamental Difference - or no Difference at All?, in: Bernstein,Drobnig and Koetz (eds.), Festschrift fuer Konrad Zweigert, Tuebingen, 1981, p. 381-393.

${ }^{61}$ Article 5 of the Act on Courts, Narodne novine 3/94, 100/96, 115/97, 131/97, 129/00, 67/01, 5/02, 101/03, $117 / 03,17 / 04$, and 141/04.

${ }^{62}$ The Constitution as a source of law for judges is expressly mentioned not only in the Act on Courts, but in the Constitution itself. See Article 117 of the Croatian Constitution, Narodne novine 41/2001, consolidated text.

${ }^{63}$ For example, Croatia has been a party to the European Convention on Fundamental Human Rights since 1997. A web search of available case law (at www.vsrh.hr) resulted in 0 cases of direct application of the European Convention by ordinary judges in resolving a dispute. There are, however, a few examples of direct application of some other international treaties by ordinary courts, such as the Vienna Convention on the International Sale of Goods (see decision by the Croatian Supreme Court, VSRH II Rev - 61/99-2) or of some international maritime conventions (see decision by the Croatian Supreme Court, VSRH Gzz 8/1992-2).

${ }^{64}$ Article 37 of the Constitutional Law on the Constitutional Court, Narodne novine 49/2002.
} 
Constitutional Court. ${ }^{65}$ Thus, either all of Croatia's laws are perfectly written, or judges simply do not question their validity. As the former is less probable, it is justifiable to ask why judges do not question the statutes. The reason is probably twofold. Firstly, judges do not take the Constitution into consideration as a source of law when adjudicating cases, as they do not regard it as a normative act, but rather as if it were a political programme or a broad framework for the legal system, one which receives legal status only upon the adoption of statutes and implementing acts. Secondly, a very narrow and simplistic understanding of the separation of powers doctrine has resulted in judges regarding it as improper to question the validity of legal norms made by Parliament.

By questioning the validity of statutes in light of the Constitution, judges could participate in the domestic process of constitutionalisation. If, however, this is not the case, despite an explicit enabling clause in the domestic Constitution, one cannot expect that it will happen in a European framework, either.

As the Constitution is not taken as a source of law, it is even less probable that judges would consider other legal rules, with no formally binding legal force, to be relevant in adjudication. Thus, different possible types of soft law instruments are not being used in the judicial process. In Croatia, case law is not a source of law for judges, either, not even as persuasive authority. This is not surprising as, until recently, judicial decisions were not even reported. ${ }^{66}$ Thus, it was practically impossible to take decisions by other judges into consideration. Based probably on the belief that judges have nothing to do with creating law, and that "the law" is something written in the statutes, such that case law is irrelevant, courts' decisions were not regularly published. Judgments were published only occasionally, and then not even in their entirety, but rather only those extracts which the person preparing a publication deemed to be relevant. This situation has started to improve only recently. Since the first half of 2004, there is a new web page for the Supreme Court, ${ }^{67}$ where all new as well as many older judgments by the Court are published in their entirety ${ }^{68}$ While the decisions of ordinary courts have not been published until recently, decisions by the Constitutional Court are regularly published in their entirety in the Official Gazette, called Narodne novine. ${ }^{69}$

Ordinary courts thus do not take case law into consideration when adjudicating cases. On the other hand, the Constitutional Court has recently begun regarding case law as a legal source. Thus, for example, in a recent case brought on the basis of a constitutional complaint, the Court cited decisions by the European Court of Human Rights and the Croatian Supreme Court. $^{70}$

\footnotetext{
65 This conclusion was reached after searching the available Internet case law databases of the Croatian Constitutional Court and Supreme Court.

${ }^{66}$ In most other ex-communist countries, court rulings, at least rulings from higher courts, were published. It seems that judicial decisions were not made public only in Croatia and Romania.

${ }^{67}$ At www.vsrh.hr

${ }^{68}$ The search capabilities of this website are not too helpful, however. Another problem is that only decisions of the Supreme Court are published, and not those of lower instances. Due to the rather brief explanatory sections of these decisions, it is sometimes difficult to understand what a particular case was actually about.

${ }^{69}$ The decisions of the Constitutional Court are also accessible on the Court's web page at www.usud.hr

${ }^{70}$ Decision U-III/1733/2000 of 24 November 2004, paragraph 7. The case was brought by a person whose appeal in criminal proceedings had been dismissed as belated. The court of first instance that decided in the case had given incorrect instructions regarding the time limit for lodging an appeal, namely, 15 days, rather than the eight days prescribed by the Criminal Procedure Act in such cases. The appeals court dismissed the appeal as belated, basing its decision on the time limit prescribed by the Code. The Constitutional Court considered that, in this manner, the person in question had been deprived of the right to a fair trial and the right to an appeal guaranteed by the Constitution. It cited a decision by the European Court of Human Rights in order to justify its view that the procedure was to be regarded as a single whole, as well as the Supreme Court's decision confirming that incorrect instructions cannot deprive a person from the right to an appeal.
} 
Non-publication of judicial decisions has also prevented the development of discourse ${ }^{71}$ between the judiciary and academic communities, which is an important element in shaping the legal order in European countries and the EU itself. ${ }^{72}$ As Kühn notes, in Eastern Europe the task of legal scholars at universities has been to comment on the texts of the legal codes ${ }^{73}$ and, in the best case, to compare the text of domestic code in a certain area with that of other countries. Scholars have not and (as the court decisions were not published) could not comment on the interpretation of legal norms in practice. The social impact of legal norms was not, and still is not, considered important, at least not in the legal profession. All of this has also influenced legal education.

\section{b) Interpretation of the Law}

When the formalism of the $19^{\text {th }}$ century was gradually replaced by a more flexible, pragmatic approach to law in Western European countries, the prevailing method of interpretation of the law, be it statutes or that made by judges, became teleological or purposive. In order to understand what a legal rule means, judges take into account its purpose. The purpose of a norm is assessed in a contemporary context, one where the real social situation is important. The wording of a norm, while not completely unimportant, plays a secondary role.

On the contrary, judges in Eastern Europe look almost exclusively at the text of a norm when assessing its meaning in the case at hand. The unclear wording used in legal norms is understood in a way in which it has been explained by the legal doctrine in pre-formulated legal constructions, or legal concepts. Legal concepts are a world of their own, very often with little connection to reality, and very often learned at the times when a judge was still a student of law at the university. Legal concepts are also something which lawyers are very proud of: this is what makes them lawyers, because while non-lawyers can read the text of the codes, they cannot understand it, as they are not familiar with the legal concepts.

That the text of a norm is considered to be all that matters in its interpretation can be demonstrated by a few examples from Croatian legal practice. The first example concerns the interpretation of the Enforcement Act. The case was the following: Mr. X, ${ }^{74}$ the absolute guarantor to a debt owed to a certain financial institution, refused to pay the debt voluntarily. The creditor brought a court action against him, and the court ordered him to pay the sum owed together with interest. As Mr. X still refused to pay, the creditor started enforcement proceedings in the Municipal Court in Virovitica. After two unsuccessful public auctions, at which nobody bid for the debtor's property, the court accepted an offer of HRK $1^{75}$ at the third auction in December 2000, and sold the property. The only bidder was the creditor himself. The property thus sold consisted of a house, land, and an orchard. Its value was estimated at HRK 62,267, while the total debt thus enforced was HRK 19,708. Mr. X lodged an appeal against the order by the Municipal Court with the County Court in Bjelovar. In January 2001,

\footnotetext{
${ }^{71}$ On the importance of discourse for the creation of a legal order and differences in discourse in democratic and communist countries, see Rodin, S., Discourse and Authority in European and Post-Communist Legal Culture, published in this issue.

${ }^{72}$ On the importance of interaction between doctrine and the courts, see Van Hoecke, M./Warrington, M., Legal Cultures, Legal Paradigms and Legal Doctrine: Towards a New Model of Comparative Law, (1998) 47 International and Comparative Law Quarterly 495, p. 523 et seq.

${ }^{73}$ Z. Kühn, Worlds Apart. Western and Central European Judicial Culture at the Onset of the European Enlargement, see n. 52

${ }^{74}$ In Croatia, names of parties to a case are not reported when court decisions are published.

${ }^{75}$ EUR 1 = approx HRK 7.5
} 
the latter upheld the order by the Municipal Court. Mr. X then lodged a constitutional complaint with the Constitutional Court, which nullified the decisions of both the Municipal Court and County Court. ${ }^{76}$ The ordinary courts based their decisions to sell the property for only HRK 1 on Article 97/4 of the Enforcement Act, which then read as follows: "If the immovable property is not sold at the second auction, the court will, within at least 15 and at most 30 days, organise a third auction, at which the immovable property may be sold without a minimum lowest price in relation to its established value (...)" ${ }^{77}$ Both the Municipal Court and the County Court based their decisions exclusively on the text of the provision quoted, which they interpreted as meaning that the court could not refuse any offer. ${ }^{78}$ They entirely disregarded the purpose of the enforcement proceedings, which was to settle the debt, not to punish the debtor. ${ }^{79}$ They also interpreted the provision in question outside any context. They even disregarded other provisions of the Enforcement Act, ${ }^{80}$ not to mention the wider legal context, including constitutional guarantees, based on which the Constitutional Court nullified their decisions in the constitutional complaint procedure.

Another example concerns a case in which a person claimed damages from the Republic of Croatia due to invalidity arising from his service in the Yugoslav Army. Three courts - the Municipal Court of Imotski in the first instance, the County Court of Split on appeal, and the Supreme Court in revision proceedings - opined that the Republic of Croatia could not be sued, as it was not the successor to the obligations of the former Yugoslavia. The Supreme Court explained its decision as follows: "The fact that damages were caused to a citizen of the Republic of Croatia is not sufficient in itself, in the absence of a specific act on succession in this regard...". ${ }^{81}$ What the Supreme Court was looking for was a specific act in Croatian law (a statute or similar) which would explicitly stipulate that Croatia had assumed tortious liability for acts or omissions of the former Yugoslavia. In the absence of such a specific provision, the ordinary courts concluded that a tortious liability could not exist. The claimant lodged a constitutional complaint with the Constitutional Court, which invoked constitutional guarantees and international law to nullify all three decisions by the ordinary courts. ${ }^{82}$ These sources were not even considered by the ordinary courts, including the Supreme Court, as potentially relevant to the case in question.

Formalism in interpretation by ordinary courts is so entrenched that the Constitutional Court has felt the need to explicitly warn them not to base their decisions exclusively on formal criteria. ${ }^{83}$ However, the Constitutional Court itself has sometimes given a very narrow and formalistic interpretation of the Constitution. Thus it was unable, in a series of decisions, to determine that the guarantee of a fair trial includes the right to receive a decision regarding a person's rights within a reasonable time. According to the Constitutional Court, the right to a fair trial within a reasonable time did not exist in Croatia before its ratification of the

\footnotetext{
${ }^{76}$ Case U-III/488/2001. Only the decision of the Constitutional Court was published. Thus, all information given in this text is as given in that decision. See also case U-III/1112/2001.

${ }^{77}$ In Croatian, Article 97/4 OZ read as follows: “Ako nekretnina ne bude prodana ni na drugom ročištu, sud će u roku od najmanje 15 do najviše 30 dana zakazati treće ročište na kojemu nekretnina može biti prodana bez ograničenja najniže cijene u odnosu na utvrđenu vrijednost.(...)".

${ }^{78}$ As reported in the decision of the Constitutional Court U-III/488/2001 in its paragraph 4.

${ }^{79}$ This was also pointed out by the Constitutional Court in paragraph 8 of decision U-III/488/2001.

${ }^{80}$ Article 6 of the Enforcement Act provides that, during enforcement proceedings, the dignity of the person against whom the enforcement is being undertaken should be taken into consideration, and that the enforcement is to be implemented in a manner which is least disadvantageous for the person against whom it is being undertaken. Article 70 of the Enforcement Act provides that enforcement of a monetary debt cannot be executed on property necessary for the life of the person against whom it is being undertaken and his dependents.

${ }^{81}$ Decision by the Constitutional Court in case U-III/273/1999 of 21 February 2001, paragraph 4.

${ }^{82}$ Decision of the Constitutional Court in case U-III/273/1999 of 21 February 2001.

${ }^{83}$ Decision of the Constitutional Court in case U-III/956/1999 of 5 April 2000.
} 
European Convention on Human Rights and Fundamental Freedoms in 1997. The Constitution was amended on 9 November 2000, and today its Article 29 expressly provides for the reasonable time requirement. Before this amendment, the right to a fair trial was guaranteed by the Constitution, yet without explicit reference to a reasonable time requirement. The Constitutional Court did not deem it appropriate to infer this right either from the general constitutional framework or, even more obviously, from the express right to a fair trial, which had been guaranteed by Article 29 of the Constitution since 1990, but only amended in 2000 to include the right to a judicial decision within a reasonable time. ${ }^{84}$ This is an example of the Constitutional Court's inability to construe an existing provision of the Constitution in any other way than by a literal reading of its text.

Just as ordinary judges never apply the Constitution directly, either as a source of rights and obligations, or as norm against which the validity of other norms may be assessed, they also never use it in interpreting statutes. This neglect of the Constitution is not an exception, but rather the rule in judicial circles. This is why the Constitutional Court has cautioned judges that the Constitution also has interpretative effects. ${ }^{85}$ Thus, in a recent case concerning the procedural time limit in bankruptcy proceedings, the Constitutional Court stated the following:

"The Constitutional Court considers it important to refer to the provision of Article 117, paragraph 3 of the Constitution, which reads: 'Courts adjudicate on the basis of the Constitution and legal acts'. Therefore, interpretation and application of a legal provision must take into consideration the provisions of the Constitution which guarantee constitutional rights and fundamental freedoms." 86

As textual interpretation is still the principal method of interpretation used in ex-communist countries, the purpose of a rule and, therefore, the context in which it exists are not considered by judges. The social context is rarely taken into account in their judgments, and even more rarely mentioned. Examples of decisions in which judges actually have justified their interpretation of the law by reference to a social context demonstrate that they are prone to misunderstand what this means. Thus, the Chamber of the County Court of Gospić sentenced a person of Serbian nationality to 13 years in prison for crimes against prisoners of war, explaining its decision by referring, among other things, to the "fact" that the "Serbian people have been committing genocide against Croats... for over 500 years" ${ }^{87}$ This example shows that a de-formalisation of the legal system, which gives judges greater freedom and creativity in interpretation, but also requires a level of social responsibility from them, will not be easy to achieve. Rather, it may easily turn into a situation where the context in which judges determine the purpose and meaning of a norm is merely their own personal view. This is not to say that personal views do not influence judicial decisions, only that judges must be aware that there are limits to this. Although these limits are not easy to define in general, it is clear that they may be found by examining the policy surrounding the legal norms, as expressed in,

\footnotetext{
${ }^{84}$ See, for example, decisions of the Constitutional Court U-III A/2933/2002 and U-III/A2303/2003.

${ }^{85}$ Even though Croatian Constitutional Court did engage in a dialogue with the ordinary courts, its influence on changes of legal culture in the ordinary courts is far less important than in some other countries of Central and Eastern Europe, like, for instance, Chech Republic. See in this respect, Z. Kühn, Worlds Apart. Western and Central European Judicial Culture at the Onset of the European Enlargement, see n. 52

86 Decision of the Constitutional Court in case U-III/1569/2001 of 9 December 2004, paragraph 6. In the original, it reads as follows: "Ustavni sud ocjenjuje važnim istaknuti odredbu članka 117. stavka 3. Ustava koja glasi: 'Sudovi sude na temelju Ustava i zakona'. Stoga, tumačenje i primjena neke zakonske odredbe mora uvažavati odredbe Ustava kojima su zajamčena ustavna prava i temeljne slobode."

${ }^{87}$ This decision was nullified by the Supreme Court on a number of grounds, and was returned for retrial before a completely different chamber, due to the aforementioned explanation by the judges presiding over the previous trial. Only the decision of the Supreme Court was published, as No. I KŽ 862/03-8 of 29 January 2004.
} 
among other things, soft law instruments, as well as considering the consequences of this or that interpretation not only for the person before the court, but also for society in general. And this is something which formalist judges do not take into account.

The non-publication of judicial decisions in Croatia (as mentioned above) has also prevented the public's involvement in the formation of judicial opinions regarding the appropriate interpretation of legal norm(s). Even today, commenting in public on a court's decisions which are not res iudicata is regarded as undue influence on the judges (endangering their independence), and is even punishable. ${ }^{88}$ The result of this is that judicial decisions are not published until they have reached that state of the proceedings where they can no longer be challenged. As it often takes very long for a judicial process to reach a phase where no further legal remedies are available to the parties, ${ }^{89}$ this can postpone comment on a judicial decision to the point where it becomes irrelevant. However, the situation has been improving in recent years, as important court proceedings, especially those related to the recent war, or corruption and organised crime, are receiving more and more publicity in the media. Thus public discourse has been enabled, informing judges of the social implications of different outcomes in such cases.

\section{c) Argumentation}

Another element of legal culture previously mentioned here is the theory of argumentation; in other words, the question of what arguments can be used in interpreting the law - only legal ones, or others as well? From what was stated earlier, it should already be obvious that nonlegal arguments are not regarded as valid in the judicial process in Central and Eastern Europe. Rather, arguments are based on the text of legal norms or legal concepts. Only if a legal concept refers to another type of argument, such as statistics or the like, can they be taken into account. It is, therefore, doubtful whether Croatian courts will be able to apply, for example, the principle of effectiveness as the guiding principle defining the powers and duties of national courts as Community courts, or the principle of non-discrimination, especially in recognising cases of indirect discrimination.

Although there have been certain improvements, Croatian judges still function in a system which is largely formalistic and denies judges any role in creating the law. Judges' perception of their own role fits into this system. They see themselves as mechanical appliers of written law, which contains the solutions to all possible real-life situations, so that all disputes may be resolved by pure deductive logic. ${ }^{90}$ Such a self-perception does not place them on a equal footing with the other branches of government. For this reason, judges lack the ability to

\footnotetext{
${ }^{88}$ Article 309 of the Criminal Code, Narodne novine 110/97, as amended in Narodne novine 111/2003.

${ }^{89}$ The slowness of the judicial process and the backlog of cases awaiting decision are a huge problem in the Croatian judicial system. This has already resulted in Croatia's being sued before the European Court of Human Rights for breaching Article 6 of the European Convention on Human Rights and Fundamental Freedoms. For more about this, see A. Uzelac, The Rule of Law and the Judicial System: Court delays as a barrier to accession, Croatian Accession to the European Union. Institutional Challenges, ed. by Katarina Ott, Institute of Public Finance, Zagreb, 2004, p.105.

${ }^{90}$ Recently, the President of the Croatian Supreme Court has, on several occasions, expressed his apprehension at a flood of new legal norms resulting from the process of adjustment to the acquis. The reason for such apprehension is that judges cannot learn all these norms as quickly as they are created. However, if judges are not viewed as mechanical appliers of legal rules, then it is not necessary that they "learn" the new rules. They need only be able to consult them when deciding a case, understand their purpose within a given social context, and interpret and apply them accordingly. In such a view, the legal rule as a written text is only one element of the input judges need to properly apply the law.
} 
participate in any kind of dialogue on shaping the legal system. This is because they do not see themselves as part of the law-making process. In fact, it is their view that, by admitting that they do indeed have a role in creating the law, their own independence would be endangered.

A certain amount of time will be necessary in order for the legal culture to change. The question which arises, therefore, is whether such judges, with their formalistic view of the law, can function as general courts of EU law, even though they may not yet participate in shaping the legal system. If the answer is negative, then the recent EU enlargement may prove problematic, as judges from eight of the new Member States could endanger the functioning of the EU's legal system. ${ }^{91}$ In the following section, I will try to demonstrate that, with a proper education in EU law, even formalistic judges can function in the EU legal order. Although it is to be expected that certain principles of EU law, such as the principle of effective judicial protection, will remain largely unapplied, this will not endanger the EU legal order's functioning to such a degree that enlargement ought to have been postponed. There are, in fact, good arguments not to postpone further enlargement due to persistent judicial formalism, as EU membership will probably speed up the necessary changes.

\section{Domestic Courts as General Courts of EU Law}

As courts of general jurisdiction for all questions of Community law that are not in the exclusive jurisdiction of European courts, national courts must apply not only the Treaties and European legislation, but also a number of judge-made principles. It should not be very difficult to teach judges about the influence which some of these principles have on their powers and obligations in litigation. It is easy to understand, for example, that direct effect and supremacy require a judge to apply a legal norm contained in a directive instead of a legal norm from the national code, should the two differ. It is also not too complicated to understand that, in the present position of the ECJ, a directive should not be directly applied if it imposes an obligation on an individual which national law does not impose. It is also easy to explain that when EC law is in question, a judge is not permitted to ask the national constitutional court to invalidate a norm in the national code, but rather must disapply it in his own decision. ${ }^{92}$ This will be even easier if the national constitutional order has been adjusted to the requirements of EU membership prior to accession, as was the case in many of the new Member States. ${ }^{93}$

\footnotetext{
${ }^{91}$ It is still too early to evaluate how the national courts of the new Member States are performing their role as European courts.

${ }^{92}$ As explained previously, Croatia's Constitutional Law on the Constitutional Court and its Act on Courts establish a procedure for centralised judicial review of primary legislation. Thus ordinary judges are not empowered to decide on the constitutionality of statutes, but rather are obliged to stay the procedure and refer the constitutionality issue to the Constitutional Court. This situation is similar to that in Italy before the Simmenthal case (see n.15) was decided.

${ }^{93}$ Slovenia's constitution was amended in March 2003, Hungary's in December 2002, the Czech Republic's in June 2002 and Latvia's in June 2003, while Estonia's and Lithuania's constitutions were complemented by new constitutional acts in September 2003 and July 2004, respectively. The Polish constitution was not specifically amended for the purposes of EU membership, but was adjusted via interpretation. As far as candidate countries are concerned, Romania adjusted its constitution for EU membership purposes in 2003, while Bulgaria has still not undertaken the amendment process. For more about constitutional adjustments for EU membership purposes, see: The Hopes and Fears of New Member States and (Pre)Candidate Countries, Asser Institute, forthcoming in 2005.
} 
Judges can easily learn the judicial aspects of Community law principles and the consequences these have on their powers and obligations, or, in other words, what they must and must not do when adjudicating a Community law case. While this will enable them to apply Community law, it will not, however, prepare them to take part in constitutional discourse. The latter requires not only mechanical application of the principles learned, but also a critical assessment of them, either in relation to the internal legal order or as part of the European legal order. Thus it is unlikely that an Eastern European judge would question the ECJ's denial of the horizontal effect of EU directives, as the Italian judge did. ${ }^{94}$ This is because, once he learns that directives do not have effects in horizontal relations, he will not question this principle, but simply apply it. Whether the judge likes the consequences of such a solution or not will not figure into his adjudication. An Eastern European judge will simply not consider this to be a question that concerns him. His job is to apply the directive in a vertical situation, and to apply national law in a horizontal one. And since this is the law, the judge cannot and will not question it. Once he has learned what the positive law is (at one of the many seminars on Community law that have been or will be organised, many of them financed through Community programmes ${ }^{95}$ ), he will apply it. Thus, paradoxically, the positivism and formalism of Eastern European judges may sometimes make them "good European judges", i.e. judges who faithfully apply Community law.

There are, however, certain Community legal principles which a formalistic judge will have difficulty in applying, as their consequences cannot be simply listed and learned. One such principle is the principle of effectiveness, or effective judicial protection, which requires judges to assess the effectiveness of all applicable national rules where Community rights are in question and, should he find them ineffective, to modify them. There is no easy formula according to which one may assess whether a national procedural rule satisfies the requirement of effectiveness, i.e. whether it makes protection of Community rights "practically impossible or excessively difficult". ${ }^{96}$ It may, therefore, happen that national judges will not even apply this principle unless the lawyers of the parties to a case raise the issue. The outcome might then be that an ineffective domestic rule will be applied. However, it is quite likely that this happens in the courts of existing Member States on a daily basis. ${ }^{97}$ On the assumption that there are not many such ineffective national rules, non-application of the principle of effective judicial protection will not endanger the Community legal order. It may only damage a party whose lawyer is not familiar enough with Community law. This will force lawyers to learn more Community law, which will, in turn, result in judges being forced to assess the effectiveness of national rules. If they are not sure how to do this, they will learn to use the preliminary ruling procedure and have the ECJ give them the answer (even if only

\footnotetext{
${ }^{94}$ The Giudice Conciliatore of Florence justified its reference to the ECJ in Faccini Dori (see n. 41), whereby it asked the ECJ to reconsider its denial of the horizontal direct effect of directives, in the following way: "If the directive could be relied on only as against the State, that would be tantamount to a penalty for failure to adopt legislative measures of transposition as if the relationship were a purely private one." Case Faccini Dori,see n.41, para. 21.

${ }^{95}$ For a criticism of education programmes in Community law during the pre-accession period, see F. Emmert, Administrative and Court Reform in Eastern and Central Europe, (2003) 9 (3) ELJ 288.

${ }^{96}$ See, for example, case Amministrazione delle Finanze dello Stato v. SpA San Giorgo, see n. 17, para. 14.

97 The available sources on Member States' case law involving the application of Community law include the Annual Reports on implementation of Community law, prepared by the Commission and available on-line and, as of recently, a bulletin prepared by the Research and Documentation Division of the ECJ under the name Reflets. The latter is available only in French at http://curia.eu.int/en/coopju/apercu_reflets/lang/index.htm. These sources more often give information about the application of Community law by national courts, and less often about its non-application. In any case, it is not possible to gather information about the (mis-)application of Community law in every case before every court in all the Member States. Thus, no conclusion as to whether Member States' courts apply Community law properly or not can ever be called accurate, as it cannot be empirically verified.
} 
indirectly ${ }^{98}$ ). Indeed, there is a danger that the ECJ and, should the potential of the Nice Treaty be used, the Court of First Instance as well ${ }^{99}$ will be overburdened by preliminary references from judges in new Member States. ${ }^{100}$

The other problem for Croatian judges in applying judge-made law lies in the custom of not publishing judgments, due to which they are not used to following case law regularly. Thus, immediately after accession judges will probably start applying the Community law principles they have learned about at seminars organised prior to accession, but will have difficulty in applying the new principles developing in case law, should organised education during the pre-accession period (and the financing thereof) cease following accession.

Additionally, the translation of EU case law into Croatian will take time, ${ }^{101}$ while many Croatian judges do not have sufficient knowledge of foreign languages to read judgments in the existing translations. ${ }^{102}$ Furthermore, judges do not have access to and/or knowledge of the use of case law databases on the Internet. Most importantly, they claim not to have enough time to do this, given the backlog of cases they have to deal with (in Croatia, a figure of around $1,500,000$ pending cases is usually mentioned ${ }^{103}$ ) and the amount of new legislation enacted daily. The same problems, however, existed and still exist in the new Member States from the 2004 enlargement. Their experience will be of great practical value in organising the learning process for Croatian judges.

Notwithstanding these problems, the deep-rooted formalism of Croatian judges, due to which they tend to apply the rules they have learned mechanically, without questioning them, could in fact help turn them into "good European judges". For once they have learned the technical implications of Community principles, judges will apply them without question after Croatia becomes a member of the EU. They will have learned that, in conditions of EU membership, the principles of EC law apply. With the right measure of "European indoctrination", Croatian judges can easily become good European judges.

While organised education in EU law for judges has not really begun yet in Croatia, several EU law courses have already taken place. ${ }^{104}$ Given that membership in the EU is the country's

\footnotetext{
${ }^{98}$ Even though the ECJ has no jurisdiction regarding the assessment of a Member State's internal law under a preliminary ruling procedure, national courts often use this procedure to get answers about the validity of an internal rule, rather than about proper interpretation of a Community rule. If the ECJ finds such a question interesting, it will reformulate the national court's question and give an indirect answer regarding the (in)validity of the national rule in question.

${ }^{99}$ The amendments to the organisation of EU level courts proposed by the Nice Treaty envisaged the possibility of granting the CFI power to decide certain types of cases in preliminary ruling (Article 225/3 TEC). This possibility has not yet been made use of. The recently signed Constitutional Treaty does not add anything new in this respect (Article III-263/3 of the Constitutional Treaty). It only renames the Court of First Instance as the General Court.

${ }^{100}$ However, in first eight months of the membership of new States in the EU, there were only two requests for preliminary ruling by their courts, both from Hungary. Both cases are still pending. These are case C-302/04 Ynos Kft. V Varga János and case C-328/04 Vajnai Attila.

${ }^{101}$ In accordance with a legal culture that neglects case law, priority in translation is given to EU legislation.

${ }^{102}$ Many of the new 2004 Member States had not translated the entire case law by the date of their accession to the EU.

${ }^{103}$ The Commission's opinion on Croatia's application for membership states a figure of 1.38 million pending cases, COM (2004) 257 final, 20 April 2004, p. 18.

${ }^{104}$ These were organised on an ad hoc basis and financed by various foreign foundations and institutions, such as the German Foundation for International Legal Cooperation (IRZ) or the Asser Institute of The Hague. In 2004 a Judicial Academy was established within the Ministry of Justice, with the task of organising permanent education for judges. Thus this institution will probably organise most of the education in EU law for judges in
} 
number one political goal, that Croatia has received candidate status and all the funds accompanying such status, and that reform of the judiciary is among the priorities in the Commission's opinion on Croatia's membership application ${ }^{105}$ and the decision establishing a European Partnership with Croatia, ${ }^{106}$ it is to be expected that there will be plenty of programmes for educating judges in EU law. ${ }^{107}$ The recently established Judicial Academy ${ }^{108}$ is in charge of organising permanent education for judges, with EU law as its priority area. ${ }^{109}$ It is to be expected, therefore, that Croatian judges will be educated predominantly in EU law in the years to come.

However, there is little chance that Community law principles will be judicially applied prior to formal EU accession, even though there are good reasons to do so. For example, the principle of indirect effect might be applied in the pre-accession period, as large numbers of new legal codes are being passed or amended as part of the process of harmonising Croatia's legal order with the acquis communautaire. ${ }^{110}$ However, the experience of other ex-communist countries teaches us that, prior to accession, EU law will remain foreign law, and judges will not take it into consideration, even as an interpretational tool.

With the exception of the Polish Constitutional Court, ${ }^{111}$ Community law was almost completely disregarded in other Central European countries prior to their accession. Zdenek Kühn's comment illustrates this very clearly: "Apart from this field [competition law - auth.], however, judicial awareness of the Czech Association Agreement with the EU is not high, and

the future.

${ }^{105}$ Opinion on Croatia's Application for Membership of the European Union, COM (2004) 257 final, Brussels, 20 April 2004.

${ }^{106}$ Council Decision 2004/648 (see n.2) on the principles, priorities and conditions contained in the European Partnership with Croatia.

${ }^{107}$ The EU has already started financing programmes for the education of judges via the CARDS programme. There is an ongoing CARDS project aimed at helping the recently established Judicial Academy to organise permanent education for judges.

${ }^{108}$ The Academy was established in 2004 as part of the Ministry of Justice. More information about it is contained on its web page www.pravosudje.hr/centar/index.html

${ }^{109}$ However, the new institution will not make much of a difference if judges are not motivated to learn and adapt. The Present Act on Courts already envisages obligatory permanent education for judges. However, in general judges have not developed a habit of systematic self-education, the excuse very often being a lack of time and money. In this respect, see A. Kovačić, Stalna stručna izobrazba i usavršavanje sudaca, Hrvatska pravna revija, December 2001, p. 132.

${ }^{110}$ One may even argue that there is an obligation to conform judicial interpretation to EU law. Namely, both the Stabilisation and Association Agreement and the requirements imposed for EU membership require Croatia to adjust its laws to the acquis communautaire. This cannot be accomplished by the mere enactment of seemingly compatible legal norms, but rather by conforming the application of legal norms to EU law in practice. Thus interpretation of Croatian norms in light of the Community law to which they have been adjusted may be understood as an obligation undertaken under the SAA, one which is binding on the state in all respects, including the courts. A similar opinion has been expressed by the Polish Constitutional Court; see the following footnote.

${ }^{111}$ The Polish Constitutional Court interpreted the provision of the Association Agreement, whereby Poland undertook a soft obligation to harmonise its law with the acquis communautaire, as imposing on judges an obligation to conform their interpretations with Community law. In the 1997 Gender Equality in Civil Service case, this court stated: "Of course, EU law has not binding force in Poland. The Constitutional Tribunal wishes, however, to emphasise the provisions of Article 68 and 69 of the [Polish Association Agreement]... Poland is thereby obliged to use 'its best endeavours to ensure that future legislation is compatible with Community legislations'... The Constitutional Tribunal holds that the obligation to ensure compatibility of legislation (born above all, by the parliament and government) results also in the obligation to interpret the existing legislation in such a way as to ensure the greatest possible degree of such compatibility." Quoted as per Z. Kühn, Application of European law in Central European candidate countries, (2003) 28 ELRev. 551, p. 553/554. 
EU law as an interpretational tool is rarely brought into play. The Czech case law almost never goes into comparisons of the possible meanings of the domestic legislation with EU law and does not touch the issue of European dimension of domestic law. This is also the case with the Slovak courts. The Slovak Supreme Court's decision of August 25, 1999 stands as an example. In this case the Court refused to deal with EU law as an argumentative tool to interpret domestic law in a Euro-friendly way. The Court clearly did not distinguish authoritative and persuasive arguments, as in the Court's view 'the claim relating to disregard of EU directive is not relevant to assess legality of the challenged decision considering the current stage of EU integration.' In other words, European law is beyond the orbit of ordinary judiciary until the accession." 112

The same attitude towards Community law may be expected from the Croatian judiciary in the period before accession. Croatia has signed a Stabilisation and Association Agreement (SAA) with the EU. The agreement has entered into the force in February 2005. In order to implement trade-related parts of the SAA, the EC and Croatia adopted an Interim Agreement, ${ }^{113}$ which has been applied as of 1 January 2002, and entered into force on 1 March 2002.

Using the presently available databases of case law in Croatian courts, no record has been found of any case before any court whose decisions are reported in which either the Interim Agreement or SAA were mentioned. Thus, so far the Interim Agreement has never been applied in order to resolve a case, and neither the SAA nor the Interim Agreement have been used as an aid in interpreting domestic law. One reason may be that it is too soon, so that no dispute involving these agreements has arisen in practice or reached the courts. However, it is more likely that neither courts nor lawyers are aware of the existence of these agreements or their possible significance to a given case. The latter conclusion suggests itself when one considers Croatian courts' record in using other international treaties in the judicial process, either directly ${ }^{114}$ or indirectly.

For example, Croatia has been a party to the European Convention for the Protection of Human Rights and Fundamental Freedoms (hereinafter the European Convention) since 1997. As far as ordinary courts are concerned, there is no evidence that they have ever applied the European Convention directly in resolving a dispute. There are, however, a few examples in which the Supreme Court has used the European Convention for interpretational purposes. In several cases it has referred to Article 6 of the European Convention in order to interpret Croatia's Law on Expropriation ${ }^{115}$ or, more precisely, the provisions of that law that were adopted in order to bring it into harmony with the Convention, following a decision by the Constitutional Court declaring their incompatibility. ${ }^{116}$ There are also a few examples of the

\footnotetext{
${ }^{112}$ Z. Kühn, Application of European law in Central European candidate countries, see n. 111, p. 554.

${ }^{113}$ This was also the usual practice with the Association Agreements signed by Central and Eastern European countries (CEEC). Since Association Agreements are mixed agreements, their entry into force depends on ratification not only by the EC, but also by all the Member States. This process of ratification takes time. In the period between the signing of such agreements and their entry into force, the EC has signed Interim Agreements with CEECs, relating only to those parts of the Association Agreements covered by the chapter on Common Commercial Policy in the TEC, for which the EC has exclusive competence both internally and externally.

${ }^{114}$ The Croatian Constitution (Article 140) makes international treaties that Croatia has ratified a part of its legal order, placing them above the ordinary laws. Courts are empowered to apply such international treaties. The Act on Courts expressly mentions international treaties among the sources of law that judges may apply (Article 5 of the Act on Courts)

${ }^{115}$ See decisions of the Croatian Supreme Court, VSRH Gr 1-562/02-2; Gr 1-602/02-2; Gr 1- 607/02-2; and Gr $1-662 / 02-2$

${ }^{116}$ See decision of the Croatian Constitutional Court U-I/745/1999.
} 
Supreme Court referring to other international conventions, for example ILO Convention No. 131, in order to confirm its interpretation of Croatia's Law on Labour Relations. ${ }^{117}$

The Constitutional Court has a better record of applying the European Convention. It has used it as a basis for invalidating Croatian laws contrary to the Convention's provisions in its abstract judicial review procedure. ${ }^{118}$ The Court developed the now well-established principle that non-conformity of Croatian laws with an international treaty represents a breach of the principle of the rule of law and violates the Constitution. ${ }^{119}$ It has also used the European Convention as an interpretative tool, sometimes citing the case law of the European Court of Human Rights. ${ }^{120}$ There is no evidence that any ordinary court has cited the case law of the European Court of Human Rights.

Although there are some examples of the application of international treaties, these are few in number. All of them relate to international law which is legally binding in Croatia (conventions that have been ratified). I did not find any cases in which courts took Community law, either primary or secondary, into account when interpreting Croatian law. It is to be expected that, were such a proposal put to a court, its reaction would be similar to that of the Slovak Constitutional Court: ${ }^{121}$ prior to accession, Croatian courts cannot take Community law into account.

This is one argument against postponing membership in the EU until a country's judiciary has undergone cultural change, and the use of persuasive sources of law has become common practice. Providing that judges learn the basics of Community law, they will be willing to apply it, however mechanically, once a country joins the EU. Moreover, application of Community law and its principles will most likely speed up the necessary change in legal culture, leading to the complete transformation of ex-communist legal systems into modern judiciaries capable of responsible, creative legal interpretation and open to new ideas.

\section{Conclusion: Judicial Formalism and How to Eliminate It}

Although there have been certain improvements, Croatian judges still function in a system that is largely formalistic, and denies judges any role in creating the law. Judges' perception of their own role fits into this system. They see themselves only as appliers of the written law, which is objective and contains solutions to all possible real-life situations, so that every dispute may be resolved using pure deductive logic. The impact of their decisions on real life is not important, since the law has been given, and cannot be changed. Judges view the legal rules as an end in themselves, rather than as a means of achieving certain social objectives and policy choices. ${ }^{122}$ Therefore, they do not take such social objectives and policy choices into consideration in the adjudication process.

\footnotetext{
${ }^{117}$ See decision of the Croatian Supreme Court VSRH Rev-3928/1994-2.

${ }^{118}$ See, for example, decision of the Constitutional Court U-I/745/1999.

${ }^{119}$ Decision of the Constitutional Court U-I-920/1995; U-I-950/1996 of 15 July 1998, Narodne novine 41/1998.

For more, see S. Rodin, Main Accents in Practice of the Constitutional Court (1991-2001), in: CroATIAN Judiciary: lessons and perspectives, Croatian Helsinki Committee for Human Rights and Netherlands Helsinki Committee, Zagreb 2002, p. 219.

${ }^{120}$ See, for example, decisions of the Constitutional Court U-I/745/1999 or U-III / 2962 / 2002.

${ }^{121}$ See n. 112.

${ }^{122}$ See, in this regard, M. D. A. Freeman's introduction to the theories of adjudication in Lloyd's InTRODUCTION TO Jurisprudence, $6^{\text {th }}$ ed., Sweet \& Maxwell, 1994, p. 1258.
} 
Given such a self-perception, judges are not placed on an equal footing with the other branches of government. They lack the ability to participate in any kind of dialogue on shaping the legal system, for they do not see themselves as part of the law-making process. One of the reasons for this is their belief that granting judges such a role would transform them into legislators. Creativity in judicial interpretation always raises such concerns, and yet, if judges in Western European courts have not become legislators, this is not because they have strictly abided by the text of legal norms. Talking about the boundary separating legitimate development of the law by judges from legislative activity, Lord Goff commented in Woolwich Building Society v IRC (No. 2) as follows: “....although I am aware of the existence of the boundary, I am never quite sure where to find it. Its position seems to vary from case to case". ${ }^{123}$ This will probably be the most difficult task in transforming the judiciary: to allow judicial creativity, but make judges aware of the boundaries. As there is no means of prescribing these boundaries, judges will have to learn how to find them themselves. This is more an intuitive process than a logical one. And intuition cannot be imposed, but only internalised during the long process of learning to understand the law differently.

The change that needs to happen in order to make Croatian judges ready for European constitutionalism is, therefore, not one that will happen overnight. Yet the sooner it starts, the sooner it can be accomplished. The proper place for this change to begin are the law schools. Legal education needs to be adapted so that it can prepare future "thinking" judges. The timing for a change in the educational system is perfect. The requirements of joining the European integration process, including the Bologna Process, are pressuring the existing educational system to transform. These external pressures may overcome the internal inertia of the system. Provided this transformation does not remain merely formal, but also brings changes in the curricula, syllabuses and methods of legal education, future Croatian judges will be prepared to participate in European constitutional discourse. ${ }^{124}$

As the transformation of legal culture will take time, the question to be raised is whether a country should obtain EU membership before it happens. The answer offered by this article is that it can. At the beginning of membership, a new EU country's judges need not necessarily be ready for their constitutionalising role. A judiciary ready to apply, but not to question and, therefore, modify and improve European legal rules will not bring new ideas and challenges to the existing legal order, yet it will also not endanger its functioning, provided that judges are educated in basic Community law. Therefore, it would be possible to grant Croatia membership status as soon as its judges "learn" Community law. By that time, its judiciary will most likely not yet have abandoned its formalism, and will continue to view itself as having only a very modest role in the legal system. For a true change in legal culture, Croatia will need more time. However, participation in the new European legal order may speed up the process of transformation of this society's legal culture, including its judiciary. This, paradoxically, may turn "good European judges" into bad ones, as they may start questioning the legal order within which they function. However, without such judges the European legal order would never have been created in the first place.

\footnotetext{
${ }^{123}$ (1992) 3 All ER 737, p. 760-761.

${ }^{124}$ See, in this regard, M.W. Hesselink, The New European Legal Culture, Nijhoff, 2001, pp.60-63.
} 